*For correspondence:

ShannonK@peds.ucsf.edu

Present address: ${ }^{\dagger}$ Celgene Corporation, San Francisco, United States; ${ }^{\text {TThermo Fisher }}$ Scientific, South San Francisco, United States; ${ }^{\circledR}$ Comprehensive Cancer Center, Institute of Experimental Cancer Research, Ulm, Germany; "Department of Pediatrics, Cincinnati Children's Hospital Medical Center, Cincinnati, United States

Competing interests: The authors declare that no competing interests exist.

Funding: See page 13

Received: 31 March 2015

Accepted: 17 July 2015

Published: 20 July 2015

Reviewing editor: Chi Van Dang, University of Pennsylvania, United States

(c) Copyright Wong et al. This article is distributed under the terms of the Creative Commons Attribution License, which permits unrestricted use and redistribution provided that the original author and source are credited.

\section{Functional evidence implicating chromosome 7q22 haploinsufficiency in myelodysplastic syndrome pathogenesis}

\author{
Jasmine C Wong ${ }^{1}$, Kelley M Weinfurtner ${ }^{1}$, Maria del pilar Alzamora ${ }^{1}$, \\ Scott C Kogan ${ }^{2}$, Michael R Burgess ${ }^{3+}$, Yan Zhang ${ }^{4}$, Joy Nakitandwe ${ }^{5}$, Jing $\mathrm{Ma}^{5}$, \\ Jinjun Cheng ${ }^{5}$, Shann-Ching Chen ${ }^{5 \neq}$, Theodore $\mathrm{T} \mathrm{Ho}^{6}$, Johanna Flach ${ }^{6 \$}$, \\ Damien Reynaud ${ }^{6 \text { III, Emmanuelle Passegué }}{ }^{6}$, James R Downing ${ }^{5}$, Kevin Shannon ${ }^{1 *}$
}

${ }^{1}$ Department of Pediatrics, University of California, San Francisco, San Francisco, United States; ${ }^{2}$ Department of Laboratory Medicine, University of California, San Francisco, San Francisco, United States; ${ }^{3}$ Division of Hematology/Oncology, University of California, San Francisco, San Francisco, United States; ${ }^{4}$ Unit of Hematopoietic Stem Cell and Transgenic Animal Models, Institut Pasteur of Shanghai, Chinese Academy of Sciences, Shanghai, China; ${ }^{5}$ Department of Pathology, St. Jude Children's Research Hospital, Memphis, United States; ${ }^{6}$ Eli and Edythe Broad Center of Regeneration Medicine and Stem Cell Research, Department of Medicine, University of California, San Francisco, San Francisco, United States

Abstract Chromosome 7 deletions are highly prevalent in myelodysplastic syndrome (MDS) and likely contribute to aberrant growth through haploinsufficiency. We generated mice with a heterozygous germ line deletion of a 2-Mb interval of chromosome band $5 A 3$ syntenic to a commonly deleted segment of human $7 q 22$ and show that mutant hematopoietic cells exhibit cardinal features of MDS. Specifically, the long-term hematopoietic stem cell (HSC) compartment is expanded in $5 \mathrm{~A} 3^{+/ d e l}$ mice, and the distribution of myeloid progenitors is altered. $5 \mathrm{~A} 3^{+/ d e l} \mathrm{HSCs}$ are defective for lymphoid repopulating potential and show a myeloid lineage output bias. These cell autonomous abnormalities are exacerbated by physiologic aging and upon serial transplantation. The $5 \mathrm{~A} 3$ deletion partially rescues defective repopulation in Gata2 mutant mice. $5 \mathrm{~A} 3^{+/ d e l}$ hematopoietic cells exhibit decreased expression of oxidative phosphorylation genes, increased levels of reactive oxygen species, and perturbed oxygen consumption. These studies provide the first functional data linking 7q22 deletions to MDS pathogenesis. DOI: 10.7554/eLife.07839.001

\section{Introduction}

The myelodysplastic syndromes (MDSs) are clonal stem cell disorders characterized by ineffective hematopoiesis, morphologic dysplasia, and a variable risk of progression to acute myeloid leukemia (AML) (Elias et al., 2014). Monosomy 7 (-7) and deletions affecting the long arm of chromosome 7 [del(7q)] are highly prevalent acquired cytogenetic abnormalities in de novo and in therapy-related MDS and AML (t-MDS/t-AML) (Smith et alo, 2003). The proportion of $-7 /$ del(7q) cells is markedly increased in the hematopoietic stem cell (HSC) and progenitor compartments of MDS patients relative to $T$ and $B$ lymphocytes (Kere et al., 1987b; Abrahamson et al., 1991; Bernell et al., 1996; Will et al., 2012; Elias et al., 2014). Recent studies demonstrating quantitative changes in the frequencies of phenotypic primitive long-term HSCs, common myeloid progenitors (CMPs), and granulocyte-monocyte progenitors (GMPs) in MDS patients with $-7 /$ del(7q) further support diverse effects on hematopoiesis (Will et al., 2012; Pang et al., 2013). 
eLife digest Stem cells in the bone marrow are essential for creating new blood cells.

Myelodysplastic syndrome (MDS) is a common type of blood cancer in the elderly that occurs when blood cells fail to develop normally. Depending on which types of blood cells are affected, individuals with MDS may bleed more easily, feel weak and tired, or be unable to effectively fight off infections.

Animals and plants store their genetic information in the form of chromosomes. Humans have 23 pairs of chromosomes, with one copy inherited from the mother, and the other from the father. The bone marrow cells of many people with MDS delete a section from one of their copies of chromosome 7. As this section contains many different genes, it is difficult to fully understand which specific genes contribute to the development of MDS when one copy is lost.

Wong et al. have now genetically engineered mice to lack a section of one of their copies of chromosome 7 that is often missing in patients with MDS. Bone marrow cells from these mice exhibit many of the same abnormalities found in human MDS. For example, most of the immature blood stem cells expand, but these stem cells do not correctly specialize into mature blood cells-in particular, not enough immune cells are produced. The developing blood cells also have problems expressing several genes, including one that helps to protect the cells from damaging molecules called reactive oxygen species. These problems worsen as the mice age.

These mice provide the first evidence directly linking the missing section of chromosome 7 to abnormalities found in MDS patients. Future studies using the mice will advance our understanding of how the loss of this section of chromosome 7 interacts with other genes involved in MDS to alter the course of this disease and how it responds to treatment.

DOI: 10.7554/eLife.07839.002

Multiple studies of MDS and AML specimens with interstitial deletions on $7 q$ have implicated three putative commonly deleted segments (CDSs) at chromosome bands 7q22, 7q34, and 7q35-36 (Figure 1A) (Kere et al., 1987a; Le Beau et al., 1996; Fischer et al., 1997; Liang et al., 1998; Tosi et al., 1999; Jerez et al., 2012; McNerney et al., 2013; Hosono et al., 2014). Of these intervals, $7 q 22$ is deleted most frequently in cases of MDS or AML with a del(7q) (Le Beau et al., 1996). Targeted sequencing of candidate myeloid tumor suppressor genes (TSGs) located within a $2.5 \mathrm{Mb}$ 7q22 CDS delineated by Le Beau et al. (1996), and recent comprehensive genomic analyses of clinical specimens strongly implicate a haploinsufficient role of $7 q 22$ deletions in leukemogenesis (Kere et alı, 1989; Fischer et al., 1997; Liang et al., 1998; Tosi et al., 1999; Ebert, 2011; Jerez et al., 2012; McNerney et al., 2013; Hosono et al., 2014). Consistent with this proposed mechanism, biallelic inactivation of any $7 q$ gene is rare in MDS patients with $-7 /$ del(7q). For example, whole exome sequencing of 68 myeloid malignancies characterized by $-7 / \mathrm{del}(7 \mathrm{q})$ uncovered recurrent mutations in only EZH2 (located at 7q36; $n=4$ ) and LUC7L2 (at 7q34; $n=3$ ). Biallelic inactivation of these genes and of CUX1 (located at 7q22) was observed in a small cohort of patients with 7q isodisomy (Hosono et al., 2014). SAMD9L, RASA4, DOCK4, and MLL3 are other 7q genes that have been implicated as contributing to leukemogenesis by haploinsufficiency or epigenetic transcriptional repression (Figure 1A) (Asou et al., 2009; Zhou et al., 2011; Nagamachi et al., 2013; Chen et al., 2014; Poetsch et al., 2014). Here, we demonstrate hematopoietic abnormalities in mice with a germ line deletion of a contiguous CDS of chromosome band $5 \mathrm{~A} 3\left(5 \mathrm{~A} 3^{+/ d e l}\right)$ syntenic to a $2.5 \mathrm{Mb} 7 \mathrm{q} 22$ CDS delineated by Le Beau et al. (1996) that support a mechanistic role of 7q22 deletions in MDS pathogenesis.

\section{Results and discussion}

\section{Abnormal differentiation and repopulation of $5 \mathrm{A3}^{+/ d e l}$ stem and progenitor cells}

We generated mice carrying a $2 \mathrm{Mb}$ germ line $5 \mathrm{~A} 3$ deletion that removes 13 genes syntenic to a human 7q22 CDS (Figure 1A) (Wong et al., 2010). 5A3 $3^{+/ d e l}$ mice are smaller than wild-type (WT) littermates, and homozygous deletion of the $5 \mathrm{~A} 3$ region causes embryonic lethality before $10.5 \mathrm{dpc}$ (data not shown). Total nucleated bone marrow (BM) cell counts as well as spleen and thymus weights are reduced in mutant animals (Figure 1B-D), which maintain normal peripheral blood cell counts. 


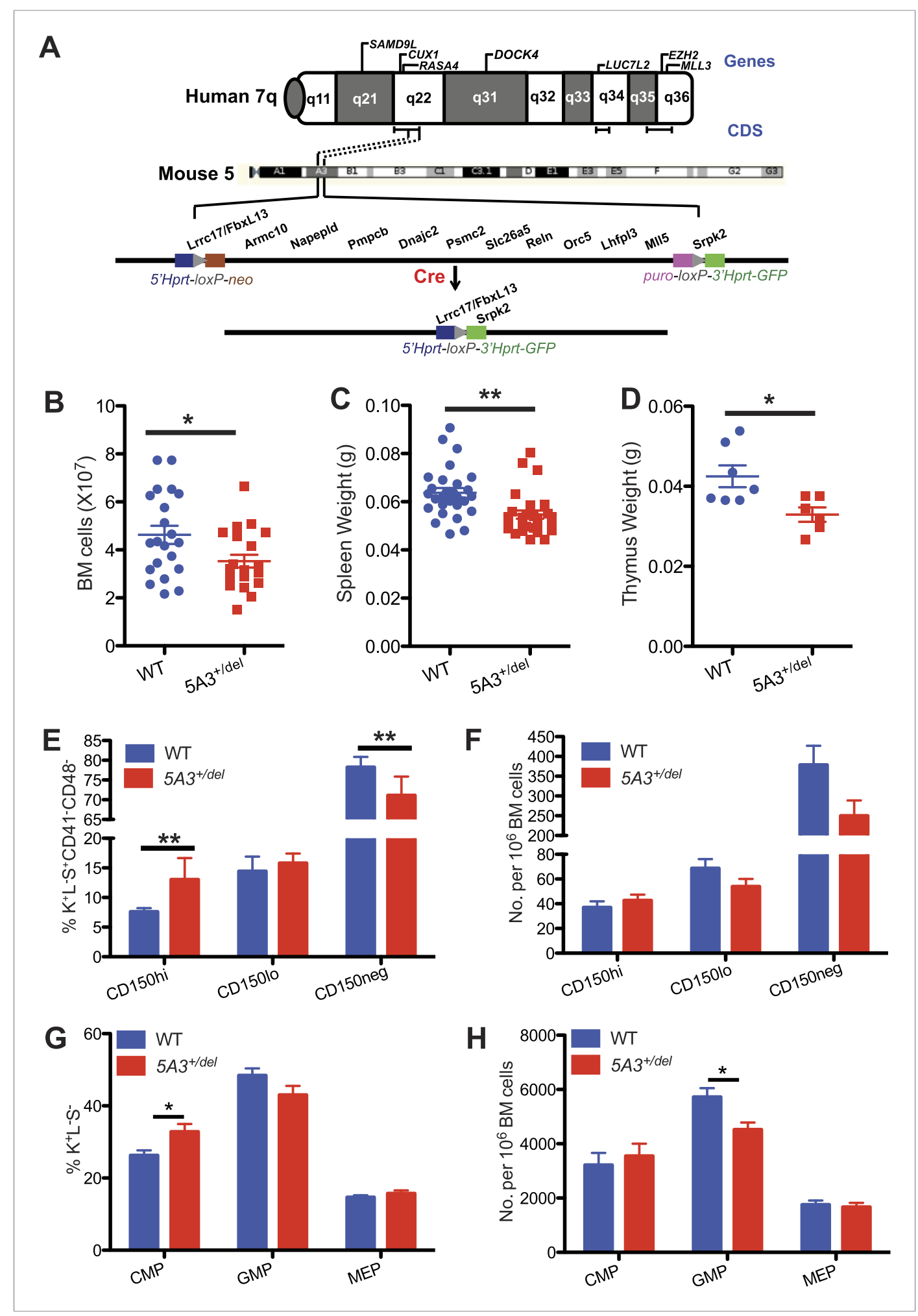

Figure 1. A heterozygous $5 A 3$ deletion corresponding to human $7 q 22$ perturbs steady-state hematopoiesis. (A) Top, candidate 7q myeloid tumor suppressor genes described previously (Asou et al., 2009; Ernst et al., 2010; Nikoloski et al., 2010; Zhou et al., 2011; McNerney et al., 2013; Chen et al., 2014; Hosono et al., 2014; Poetsch et al., 2014) appear above the diagram of chromosome $7 q$ while commonly deleted segments (CDSs) within 7q22, 7q34, and 7q35-36 identified by different research groups (Kere et al., 1987a; Le Beau et al., 1996; Fischer et al., 1997; Liang et al., 1998; Tosi et al., 1999; Jerez et al., 2012; McNerney et al., 2013; Hosono et al., 2014) are Figure 1. continued on next page 
Figure 1. Continued

depicted by brackets immediately below it. Middle, dotted lines demarcate the segments of mouse chromosome 5A3 corresponding to the human 7q22 CDS targeted in this study. Bottom, expressing Cre recombinase in embryonic stem (ES) cells doubly targeted with LoxP sequences within the Fbxl13 and Srpk2 genes excised a 2-Mb interval. Gene order is based on the Ensembl database and is not drawn to scale. (B) Total numbers of bone marrow (BM) cells from 2

femurs and 2 tibiae in 5A3+/del mice and wild-type (WT) littermates at 8-12 weeks of age. (C, D) Spleen (C) and thymus (D) weights in $5 A 3^{+/ d e l}$ mice and WT littermates at 8-12 weeks of age. (E, F) Percent contributions $(\mathbf{E})$ and frequencies $(\mathbf{F})$ of cells with high (CD150 hi HSC), low (CD150 $\mathrm{lo} \mathrm{HSC}$ ), and absent CD150 expression (CD150 neg MPP) within the $\mathrm{K}^{+} \mathrm{L}^{-} \mathrm{S}^{+}$ CD41-CD48- compartment of WT and 5A3+/del mice at 8-12 weeks of age ( $n=6$ of each genotype). (G) Percent contribution of common myeloid progenitor (CMP), granulocyte-monocyte progenitor (GMP), and megakaryocyte erythroid progenitors (MEP) within the $\mathrm{Lin}^{-} \mathrm{Sca}^{+}{ }^{+} \mathrm{c}-\mathrm{kit}^{+}$compartment of $5 \mathrm{~A} 3^{+/ d e l}$ mice and WT littermates.

(H) Frequencies of CMP, GMP, and MEP in WT and $5 A 3^{+/ d e l}$ BM. The error bars indicate S.E.M. with significant differences between $\mathrm{WT}$ and $5 A 3^{+/ d e l}$ mice designated by asterisks as follows: ${ }^{*} p<0.05,{ }^{* *} p<0.01$.

DOI: 10.7554/eLife.07839.003

The following figure supplement is available for figure 1:

Figure supplement 1. Gating strategy for hematopoietic stem and progenitor populations. DOI: 10.7554/eLife.07839.004

Differential expression of CD150 distinguishes HSC populations with different self-renewal, differentiation, and repopulating potentials. Specifically, HSCs, with a surface c-kit ${ }^{+}$, lineage ${ }^{-}, \mathrm{Sca}_{-} 1^{+}$ $(\mathrm{KLS})$, and $\mathrm{CD}_{150^{\mathrm{hi}}}\left(\mathrm{CD} 150^{\mathrm{hi}} \mathrm{HSC}\right)$ immunophenotype possess potent self-renewal capacity, are predisposed to myeloid differentiation and expand upon aging (Kiel et al., 2005; Beerman et al., 2010a; Hock, 2010). Strikingly, the proportion of CD150 hi HSCs is increased in $5 A 3^{+/ d e l} B M$ with a corresponding decrease in the percentage of CD150 negative multi-potent progenitors (CD150 neg MPP) (Figure 1E, Figure 1-figure supplement 1A). This results in a normal frequency of CD150 ${ }^{\text {hi }}$ $\mathrm{HSCs}$ in $5 \mathrm{~A}^{+/ d e l}$ mice, despite an overall reduction in the size of the stem/progenitor compartment (Figure 1F). The proportion of CMPs is elevated in $5 A 3^{+/ d e l}$ mice and the frequency of GMPs is decreased (Figure 1G,H, Figure 1-figure supplement 1B), which is consistent with changes in these populations in MDS patients (Will et al., 2012; Pang et al., 2013). Thus, the $5 A 3$ deletion perturbs HSC and myeloid progenitor populations. By contrast, the proportions and frequencies of common lymphoid progenitors are similar in WT and $5 A 3^{+/ d e l}$ mice (Figure 1-figure supplement $1 C-E$ ).

We mixed donor $5 A 3^{+/ d e l}$ or WT BM cells with WT BM at ratios of 1:1 and 1:2 and transplanted them into irradiated recipients. Whereas $5 A 3$ mutant $B M$ had markedly reduced lymphoid repopulating capacity, these cells efficiently contributed to the c-kit ${ }^{+}$lin ${ }^{-}$Sca- $1^{+}$(KLS) compartment (Figure 2A, B). To investigate if the altered repopulating potential of $5 A 3^{+/ d e l} B M$ is intrinsic to $C D 150^{\text {hi }} \mathrm{HSC}$, we injected 15 of these cells into lethally irradiated recipients with WT BM competitors. Similar to whole $\mathrm{BM}, \mathrm{CD} 150^{\text {hi }} \mathrm{HSC}$ from $5 \mathrm{~A} 3^{+/ d e l}$ mice exhibited reduced overall repopulation potential due to defective lymphoid reconstitution (Figure 2C-F). Importantly, however, 5A3 ${ }^{+/ d e l} \mathrm{HSC}$ efficiently reconstituted KLS and myeloid compartments in both primary and secondary recipients (Figure 2E,F). 5A3 ${ }^{+/ d e l}$ CD150 hi HSC exhibited markedly reduced lymphoid repopulating potential in WT and $5 A 3^{+/ d e l}$ recipients, whereas WT cells restored lymphoid repopulation in $5 A 3^{+/ d e l}$ hosts almost as well as in WT recipients, demonstrating that the repopulation defects in $5 \mathrm{~A} 3^{+/ d e l} \mathrm{CD} 150^{\text {hi }} \mathrm{HSC}$ s are cell intrinsic (Figure $2 \mathrm{C}-\mathrm{F}$ ).

$W T$ and $5 A 3^{+/ d e l}$ HSCs generated similar numbers of myeloid colonies in methylcellulose cultures supplemented with cytokines; however, colonies grown from $5 A 3^{+/ d e l} \mathrm{CD} 150^{\text {hi }} \mathrm{HSC}$ contained significantly fewer cells (Figure 2G,H). By contrast, $5 A 3^{+/ d e l}$ CD150 neg MPP showed a 1.4-fold increase in colony forming activity but a similar number of cells per colony as WT MPP (Figure 2G,I). In vivo labeling experiments revealed similar rates of BrdU incorporation, cell division, and apoptosis in WT and $5 A 3^{+/ d e l}$ $\mathrm{K}^{+} \mathrm{L}^{-} \mathrm{S}^{+}$and myeloid progenitor (MP) cells (Figure 2-figure supplement $1 \mathrm{~A}, \mathrm{~B}$ and data not shown) (Nygren and Bryder, 2008).

\section{Effects of aging on $5 \mathrm{A3}^{+/ d e l} \mathrm{HSC}$ and interaction with Gata2 haploinsufficiency}

Physiologic aging is characterized by impaired HSC repopulating potential, diminished lymphoid differentiation, the dominance of $\mathrm{CD} 150^{\text {hi }} \mathrm{HSCs}$ that are skewed toward myeloid differentiation and a markedly increased risk of MDS (Beerman et al., 2010a; Beerman et al., 2010 b). 


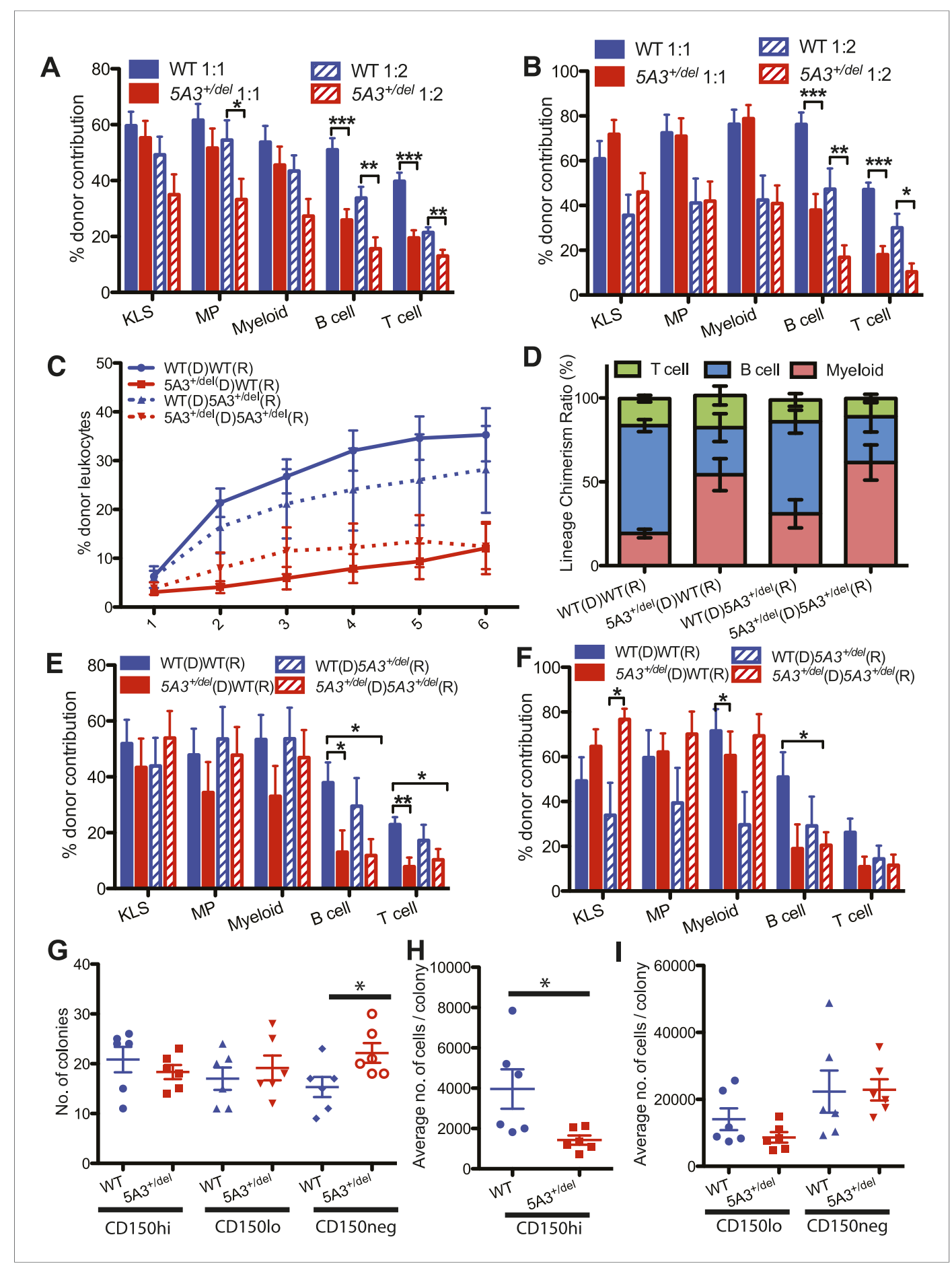

Figure 2. Defective repopulating potential of $5 A 3^{+/ d e l} B M$ and $C D 150^{\text {hi }} H S C$. (A, B) BM cells from WT or $5 A 3^{+/ d e l}$ mice ( $n=9$ per genotype) were mixed at ratios of $1: 1$ and 1:2 with WT competitor cells and transplanted into 2-3 irradiated WT recipients. Percent contribution to the $\mathrm{K}^{+} \mathrm{L}^{-} \mathrm{S}^{+}(\mathrm{KLS}), \mathrm{K}^{+} \mathrm{L}^{-} \mathrm{S}^{-}(\mathrm{MP})$, myeloid, $\mathrm{B}$ and $\mathrm{T}$ cell lineages in the $\mathrm{BM}$ of recipient mice 6 months after primary $(\mathbf{A})$ and secondary $(\mathbf{B})$ transplants are shown. (C) Leukocyte chimerism after competitive transplantation of $155 \mathrm{~A} 3^{+/ d e l}$ or WT CD150 hi HSC into WT or mutant recipients ( $n=12$ for WT hematopoietic stem cell (HSC) in WT recipients; $n=12$ for $5 A 3^{+/ d e l}$ HSC in WT recipients; $n=8$ for WT HSC in $5 A 3^{+/ d e l}$ recipients; $n=9$ for $5 A 3^{+/ d e l} H S C$ in $5 A 3^{+/ d e l}$ recipients). (D-F) Relative proportions of donor-derived $B$, $\mathrm{T}$, and myeloid cells in the blood of recipient mice 6 months after transplantation (D). Percent contribution to the $\mathrm{K}^{+} \mathrm{L}^{-} \mathrm{S}^{+}(\mathrm{KLS}), \mathrm{K}^{+} \mathrm{L}^{-} \mathrm{S}^{-}(\mathrm{MP})$, myeloid, $\mathrm{B}$ and $\mathrm{T}$ cell lineages in the BM of recipient mice 6 months after primary $(\mathbf{E})$ and secondary $(\mathbf{F})$ transplants. Data shown are mean values \pm SEM of results from four independent experiments. Figure 2. continued on next page 
Figure 2. Continued

(G-I) 100 CD150 hi HSC, CD150 ${ }^{\text {lo }} \mathrm{HSC}$, and CD150 neg MPP from 8- to 12-week-old 5A3 ${ }^{\text {t/del }}$ mice and their WT littermates were plated into methylcellulose medium supplemented with cytokines ( $n=6$ for each genotype). The total number of colonies $(\mathbf{G})$ and the average number of cells per colony $(\mathbf{H}, \mathbf{l})$ were assessed after 7 days. Dots represent individual mice, and the horizontal lines indicate median values. Data shown are mean values \pm SEM of results from three independent experiments with significant differences between WT and $5 \mathrm{~A} 3^{+/ d e l}$ mice designated by asterisks as follows: ${ }^{*} p<0.05,{ }^{* *} p<0.01,{ }^{* * *} p<0.001$.

DOI: 10.7554/eLife.07839.005

The following figure supplement is available for figure 2:

Figure supplement 1. Proliferation and divisional kinetics of $5 A 3^{+/ d e l} \mathrm{HSCs}$. DOI: 10.7554/eLife.07839.006

Similarly, the abnormal distribution of HSCs is exacerbated in 24- to 30 -month-old $5 A 3^{+/ d e l}$ mice (Figure 3A,B). Consistent with data from younger mice (Figure 2A-F), aged 5A3 mutant BM displayed markedly reduced lymphoid repopulating potential, but efficiently contributed to myeloid reconstitution (Figure $3 C, D$ ). Old $5 A 3^{+/ d e l} \mathrm{BM}$ cells also repopulated the $\mathrm{KLS}$ compartment significantly better than WT BM in recipients analyzed 4 months after transplantation, and $5 \mathrm{~A} 3^{+/ d e l}$ cells exhibited a twofold increase in contribution to the KLS and MP populations upon serial transplantation (Figure 3C,D). Despite these HSC abnormalities, $5 A 3^{+/ d e l}$ mice have a normal lifespan, and the underlying causes of death are similar to WT littermates (data not shown).

GATA2 mutations cause familial MDS, which is frequently characterized by $-7 /$ del(7q) (Hahn et al., 2011; Bodor et al., 2012; Pasquet et al., 2013). We generated Gata2 ${ }^{+/-} ; 5 A 3^{+/ d e l}$ mice, quantified HSC and progenitor populations, and performed competitive repopulation experiments. Like $5 A 3^{+/ d e l}$ mutant mice, Gata2 ${ }^{+/-} ; 5 A 3^{+/ d e l}$ mice have reduced BM cellularity and spleen weights (Figure $3 E, F$ ), and the CD150 hi HSC bias is augmented by concomitant Gata2 deletion (Figure 3G). Whereas lymphoid reconstitution is similarly impaired in $5 \mathrm{~A} 3^{+/ d e l}$ and compound mutant mice, the $5 \mathrm{~A} 3$ deletion partially rescues the repopulating deficit of $\mathrm{Gata}^{+/-} \mathrm{BM}$ in the KLS, MP, and myeloid compartments (Figure 3H) (Rodrigues et al., 2005). These data suggest that the 7q22 CDS contributes to transformation in familial MDS by impairing lymphoid differentiation while also modestly enhancing the growth of GATA2 mutant HSC and their myeloid progeny.

\section{Changes in gene expression and metabolic activities in $5 \mathbf{A 3}^{+/ d e l}$ hematopoietic cells}

Transcriptome (RNA-Seq) and TaqMan quantitative real-time PCR analyses revealed a $\sim 50 \%$ reduction in the expression of multiple genes and of the long intergenic non-coding RNA 503142E22Rik within the $5 A 3$ interval in mutant HSC and MPP (Figure 4A,B). Gene Set Enrichment Analysis (GSEA) of the RNASeq data from $5 A 3^{+/ d e l} \mathrm{HSC}$ s further demonstrated reduced expression of multiple gene sets related to oxidative phosphorylation (OXPHOS) that are similarly down-regulated in the early stages of human therapy-induced MDS and AML (Figure 4C) (Mootha et al., 2003; Li et al., 2011). OXPHOS is the metabolic pathway used by cells to generate adenosine triphosphate (ATP). OXPHOS is regulated by mitochondrial membrane potential, and defects in this metabolic pathway can increase levels of reactive oxygen species (ROS). However, sorted WT and $5 A 3^{+/ d e l} \mathrm{HSC}$ and MPP showed similar ATP levels (Figure 4D). Membrane potential and intracellular ROS levels were also similar in HSC and MPP from young mice, but ROS levels were increased by $25 \%$ in the HSC and MPP of aged $5 A 3^{+/ d e l}$ mice (Figure 4E,F). Elevated ROS levels in HSCs correlate with reduced self-renewal capacity, impaired multi-lineage repopulating ability, and myeloid-biased differentiation (Jang and Sharkis, 2007). ROS levels are also increased in t-MDS/AML BM (Reinecke et al., 2009; Li et al., 2011).

Down-regulation of OXPHOS genes is expected to reduce mitochondrial respiration in HSC (Warr and Passegue, 2013). We attempted to directly measure oxygen consumption rates (OCRs) in $\mathrm{CD}_{150^{\text {hi }}}$ and $\mathrm{CD} 150^{\circ} \mathrm{HSC}$ but could not obtain reproducible results due to limiting cell numbers. We therefore compared the OCRs of KLS, MP, B, and T cells isolated from 1-year-old WT and $5 A 3^{+/ d e l}$ mice. $5 A 3^{+/ d e l}$ KLS cells showed a similar basal OCR as their WT counterparts, but a slightly lower maximal respiratory capacity that did not reach statistical significance $(p=0.2562)$ (Figure 4G). $5 A 3^{+/ d e l}$ MPs surprisingly showed a significantly higher basal respiration and maximal 


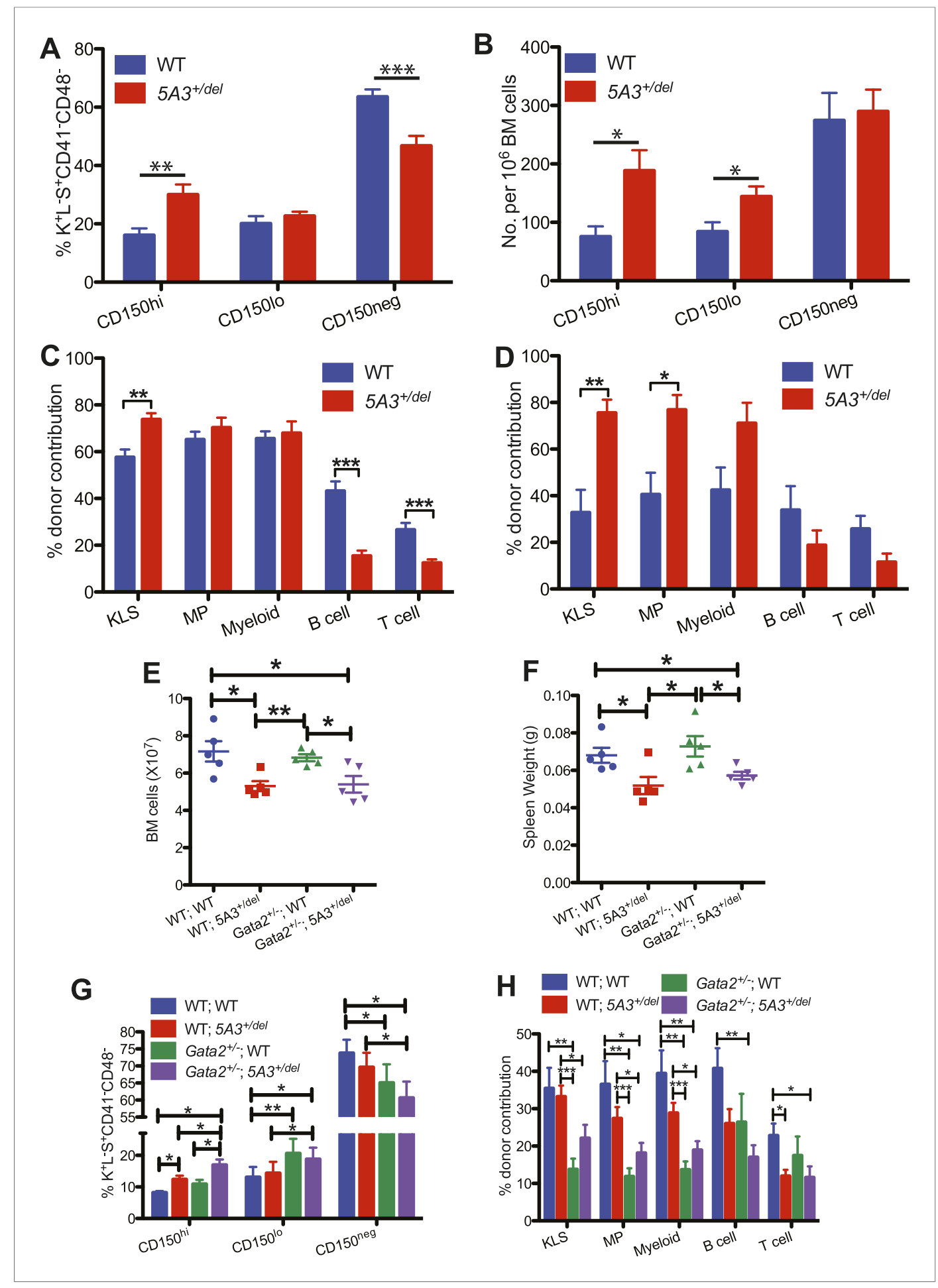

Figure 3. Effects of aging and Gata2 inactivation on $5 \mathrm{~A} 3^{+/ d e l}$ hematopoietic cells. (A and $\mathbf{B}$ ) Percent contributions (A) and frequencies (B) of CD150 hi HSC, CD150'o HSC, and CD150 neg MPP within the $\mathrm{K}^{+} \mathrm{L}^{-} \mathrm{S}^{+} \mathrm{CD} 41^{-} \mathrm{CD} 48^{-}$ compartment in $5 A 3^{+/ d e l}$ mice $(n=12)$ and their WT littermates $(n=11)$ at $24-30$ months of age. (C and D) Competitive transplantation of BM cells from 24- to 30-month-old WT or 5A3+/del mice. Percent donor contribution of $5 \mathrm{~A} 3^{+/ d e l}$ cells to $\mathrm{K}^{+} \mathrm{L}^{-} \mathrm{S}^{+}(\mathrm{KLS}), \mathrm{K}^{+} \mathrm{L}^{-} \mathrm{S}^{-}(\mathrm{MP})$, myeloid, $\mathrm{B}$ cell, and $\mathrm{T}$ cell populations in the $\mathrm{BM}$ of recipient mice 4 months after primary (C) and secondary (D) competitive transplantation ( $n=5$ donors and 10 recipients of each genotype). Data shown are mean values \pm SEM of results from two independent experiments. (E) Total numbers of BM cells from 2 femurs and 2 tibiae in $5 \mathrm{~A}^{+/ d e l}$ mice, Gata2 ${ }^{+/-}$mice, compound Gata2 $2^{+/-} ; 5 \mathrm{~A}^{+/ d e l}$ mice and WT Figure 3. continued on next page 
Figure 3. Continued

littermates at 8-12 weeks of age. (F) Spleen weights in 5A3 ${ }^{+/ d e l}$ mice, Gata2 ${ }^{+/-}$mice, compound $\mathrm{Gata2}^{+/-} ; 5 \mathrm{~A} 3^{+/ d e l}$ mice, and WT littermates at 8-12 weeks of age. (G) Percent contributions of cells with high (CD150 hi HSC), low (CD150 $\left.{ }^{\circ} \mathrm{HSC}\right)$, and absent CD150 expression (CD150 neg MPP) within the $\mathrm{K}^{+} \mathrm{L}^{-} \mathrm{S}^{+} \mathrm{CD} 41^{-} \mathrm{CD} 48^{-}$compartment of WT, $5 A 3^{+/ d e l}$, Gata2 ${ }^{+/-}$, and compound Gata2 ${ }^{+/-} ; 5 A 3^{+/ d e l}$ mice at 8-12 weeks of age ( $n=5$ of each genotype). (H) BM cells from WT, $5 \mathrm{~A} 3^{+/ d e l}$, Gata2 ${ }^{+/-}$or compound $\mathrm{Gata2}^{+/-} ; 5 \mathrm{~A} 3^{+/ d e l}$ mice ( $\mathrm{n}=5$ of each genotype) were each mixed at ratios of 1:1 with WT competitor cells and transplanted into two irradiated WT recipients. Percent contribution to the $\mathrm{K}^{+} \mathrm{L}^{-} \mathrm{S}^{+}(\mathrm{KLS}), \mathrm{K}^{+} \mathrm{L}^{-} \mathrm{S}^{-}(\mathrm{MP})$, myeloid, $\mathrm{B}$ and $\mathrm{T}$ cell lineages in the $\mathrm{BM}$ of recipient mice 6 months after primary transplants. Data shown are mean values \pm SEM from five independent experiments with significant differences designed by asterisks as follows: ${ }^{*} p<0.05,{ }^{* *} p<0.01,{ }^{* * *} p<0.001$. The enhanced repopulating ability of compound $\mathrm{Gata2}^{+/-} ; 5 \mathrm{~A}^{+/ d \mathrm{del}}$ vs Gata2 singly mutant HSC achieved borderline statistical significance in three myeloid populations (KLS ( $p=0.09), \operatorname{MP}(p=0.09)$, and myeloid cells $(p=0.12)$ ).

DOI: 10.7554/eLife.07839.007

respiratory capacity in comparison to WT cells, supporting an overall increase in energy consumption (Figure $4 \mathrm{H}$ ). Meanwhile, mature $5 \mathrm{~A} 3^{+/ d e l} \mathrm{~B}$ and $\mathrm{T}$ cells have similar mitochondrial stress profiles as WT cells. We conclude that global changes in OXPHOS gene expression exert a modest impact on cellular metabolism in aged 5A3 mutant HSC and progenitors. Interestingly, treatment with $\mathrm{N}$-acetyl-L-cysteine (NAC) did not reverse the hematopoietic abnormalities in young $5 \mathrm{~A} 3^{+/ d e l}$ mice (data not shown), suggesting that they are a direct consequence of the $5 \mathrm{~A} 3$ deletion and are not secondary to ROS production.

Segmental deletions are among the most frequent genetic alterations in human cancer, and simultaneous loss of multiple haploinsufficient TSGs that individually have minimal phenotypic consequences appears to underlie the growth advantage conferred by most of these chromosomal losses (Solimini et al., 2012). We show that a haploinsufficient deletion in mice that models loss of a human 7q22 CDS causes hematopoietic abnormalities that include a myeloid lineage output bias, impaired lymphoid repopulating potential, and a pronounced age-associated expansion of HSC and MPs. These functional abnormalities support a role of 7q22 deletions in MDS pathogenesis. The seven genes within the deleted 5A3 segment that are expressed in HSC encode proteins that regulate diverse cellular processes including transcription (MII5 and Dnajc2), mitochondrial quality control (Pmpcb, Armc10), protein degradation (Psmc2), biosynthesis of $N$-acylethanolamines (Napepld), and DNA replication (Orc5) (Luciano et al., 1997; Quintana et al., 1998; Fujiki et al., 2009; Sebastian et al., 2009; Richly et al., 2010; Nijhawan et al., 2012; Tsuboi et al., 2013; Zhou et al., 2013; Serrat et al., 2014). Given this, it is likely that the haploinsufficiency for multiple interacting genes leads to altered hematopoietic differentiation and function in $5 A 3^{+/ d e l}$ mice. Similar to the $5 A 3^{+/ d e l}$ mice described here, other mutations found in MDS patients perturb hematopoiesis, but do not consistently induce hematologic disease in the absence of cooperating mutations (Beurlet et al., 2013). This is not unexpected given the advanced age of most MDS patients and the presence of multiple genetic lesions in diseased $\mathrm{BM}$. The $5 \mathrm{~A} 3^{+/ d e l}$ mice reported here thus provide a novel resource for addressing how this common deletion cooperates with other mutations to drive myeloid transformation, progression to $\mathrm{AML}$, and drug resistance.

\section{Materials and methods}

\section{Mice}

We expressed Cre recombinase in embryonic stem cells containing LoxP sites and hypoxanthine phosphoribosyl transferase (HPRT) sequences flanking the Fbxl13 and Srpk2 genes (Wong et al., 2010) and analyzed clones that grew in hypoxanthine-aminopterin-thymidine (HAT) medium to identify the desired $2 \mathrm{Mb}$ deletion. $5 \mathrm{~A} 3^{\mathrm{del} / \mathrm{+}}$ mice were generated by standard blastocyst injection followed by mating coat color chimeras and were backcrossed for at least 10 generations onto a C57BL/6J background. Gata2 ${ }^{+/}$mice were a generous gift from Dr Stuart Orkin (Harvard Medical School) (Tsai et al., 1994). Study mice were housed in a specific pathogen-free facility at the University of California San Francisco, and all animal experiments were conducted under protocols approved by the Institutional Animal Care and Use Committee. Genotyping and disease monitoring were performed as previously described (Wong et al., 2010). 


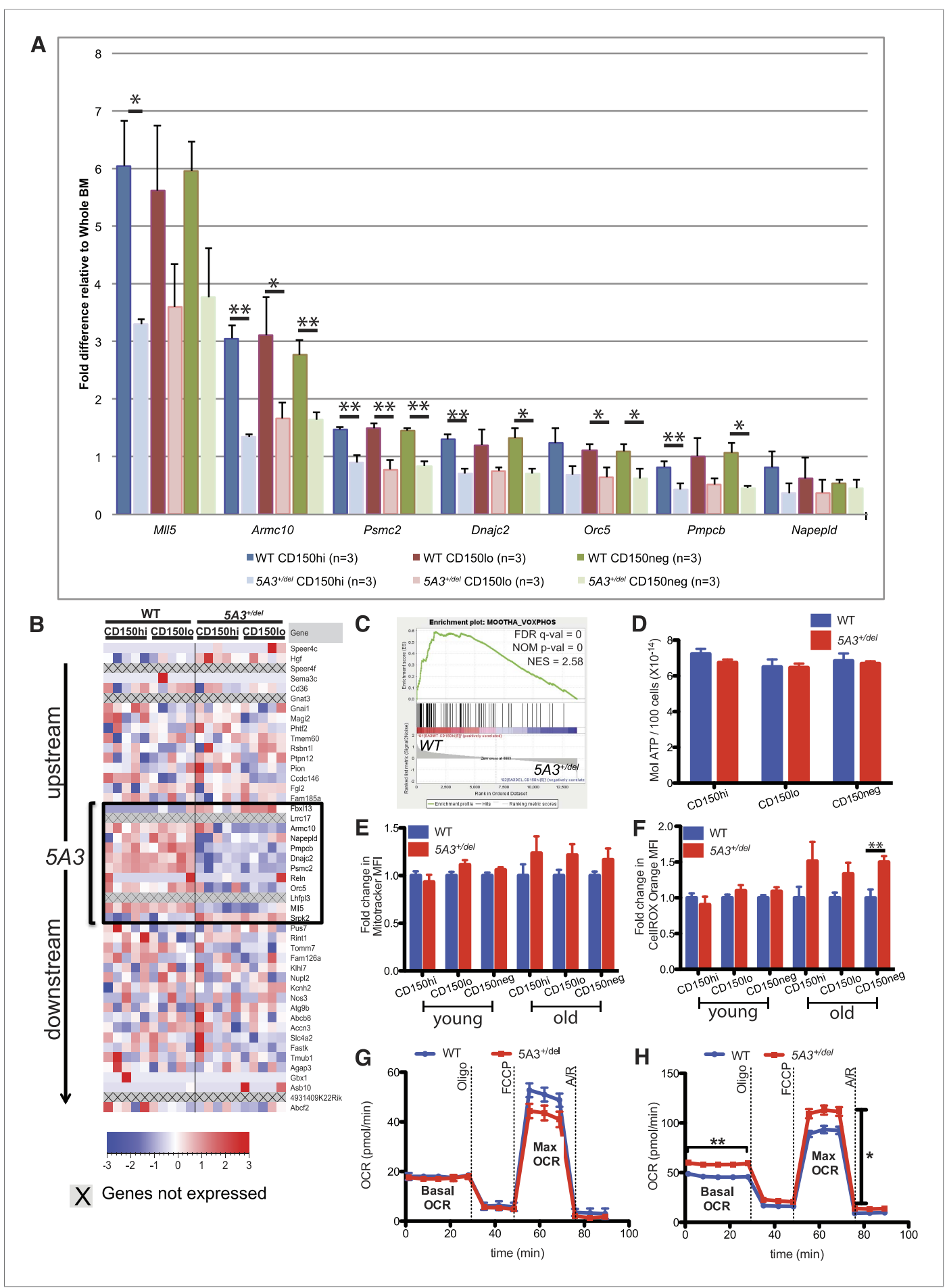

Figure 4. Changes in gene expression and oxidative phosphorylation in $5 A 3^{+/ d e l} \mathrm{HSC}$ and MP. (A) Relative mRNA abundances for genes within the deleted $5 A 3$ interval expressed at detectable levels in sorted HSC populations were determined by TaqMan reverse transcriptase PCR ( $n=3$ per genotype). (B) Expression levels of genes located within and flanking the deleted interval measured by RNA-Seq in sorted CD150hi HSC and CD150/0 HSC from 5 mice of each genotype. Each column presents data from an individual mouse, and genes within the $5 A 3$ deleted region are delimited with a black box. Three non-coding RNAs (6030443J06Rik, AC112688.1 and 5031425E22Rik) are located within the 5A3 deletion. Two of these (6030443J06Rik and AC112688.1) are expressed at extremely low levels in HSC, and the other (5031425E22Rik) showed $~ 50 \%$ lower expression in 5A3 ${ }^{+/ d e l}$ HSC. 5031425E22Rik is homologous to the human KMT2E (a.k.a. MLL5) antisense RNA1. Expression levels of the flanking Fbxl13 and Srpk2 Figure 4. continued on next page 
Figure 4. Continued

genes are modestly up-regulated in $5 \mathrm{~A} 3^{+/ d e l} \mathrm{HSC}$, which is consistent with the targeting strategy used to generate the segmental deletion. (C) Gene Set Enrichment Analysis of $5 A 3^{+/ d e l}$ CD150 hi HSCs revealed negative enrichment for genes associated with oxidative phosphorylation (OXPHOS). False discovery rate (FDR) q-val, nominal p-value (NOM p-value), and normalized enrichment scores (NESs) are indicated. (D) ATP levels in HSC and MPP from 8- to 12-week-old WT $(n=6)$ and $5 A 3^{+/ d e l}(n=5)$ mice. Data shown are mean values \pm SEM of results from two independent experiments. (E) Fold change in the mean MitoTracker Orange fluorescence levels in $5 \mathrm{~A} 3^{+/ d e l}$ cells normalized to values in WT cells analyzed in the same experiment. (F) Fold change in the mean fluorescence level (MFI) of $5 \mathrm{~A}^{+/ d e l}$ cells that are CellROX Orange positive normalized to values in WT cells analyzed in the same experiment. For the MitoTracker and CellROX experiments, $n=13$ for WT and $n=12$ for $5 A 3^{+/ d e l}$ young mice, three independent experiments; $n=5$ for WT and $n=6$ for $5 A 3^{+/ d e l}$ aged mice, two independent experiments. Data shown are mean values \pm SEM of results from independent experiments. (G and $\mathbf{H}$ ) Oxygen consumption rate (OCR) was assessed basally and in response to the mitochondrial inhibitors oligomycin (oligo), carbonyl cyanide 4-(trifluoromethoxy) phenylhydrazone (FCCP), and antimycin A and rotenone $(A / R)$ for $(\mathbf{G})$ KLS and $(\mathbf{H})$ MP cells. Data are shown as mean \pm SEM of $n=5$ mice of each genotype from two independent experiments.

DOI: 10.7554/eLife.07839.008

\section{Flow cytometry}

BM cells flushed from tibias and femurs were subjected to ammonium-chloride potassium red cell lysis before staining with antibodies. For experiments requiring cell sorting, the spinal cord, flat bone of the pelvis, humerus, and sternum of the mice were also crushed and lysed. Low-density mononuclear cells were separated using a HISTOPAQUE-1119 gradient (Sigma-Aldrich, St. Louis, MO, United States). For identification and sorting of CD150 hi-HSC, CD150'o-HSC, and CD150 neg-MPP, cells were pre-incubated with purified CD16/32 (2.4G2), followed by staining with a lineage cocktail of PEconjugated antibodies including B220 (RA3-6B2), CD8 (53-6.7), Gr-1 (RB6-8C5), CD3 (17A2), Ter119 (TER-119), CD41 (MWReg30), and CD48 (HM48-1), as well as PE-Cy7 c-kit (2B8), PacBlue Sca-1 (E13161.7), and APC CD150 (TC15-12F12.2) from BioLegend (San Diego, CA, United States). For experiments requiring cell sorting, cells expressing c-kit were enriched by magnetic cell sorting by staining with mouse CD117 microbeads and positively selected on the MS columns (Miltenyi Biotec, Germany) according to manufacturer's protocol before antibody staining. Cells were classified as

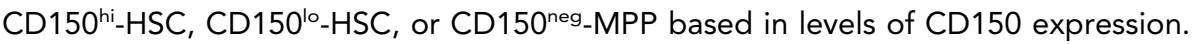

Percent contribution of common myeloid progenitor (CMP), granulocyte-monocyte progenitor (GMP), and megakaryocyte erythroid progenitors (MEP) within the Lin-Sca1+c-kit+ compartment of 5A3+/del mice and WT littermates. CMP, GMP, and megakaryocyte erythroid progenitors (MEP) populations were identified by flow cytometry after staining with a lineage cocktail of PE-conjugated antibodies including B220 (RA3-6B2), CD8 (53-6.7), Gr-1 (RB6-8C5), CD3 (17A2), and Ter119 (TER119), as well as APC-750 c-kit (2B8), PacBlue Sca-1 (E13-161.7), Alexa Fluor 647 CD16/32 (93), biotin CD34 (MEC14.7), and a streptavidin PE-Cy7 conjugate (BioLegend). Stained BM cells were analyzed in a FACS LSRII instrument and sorted in a FACS Aria3 (Becton Dickinson, San Jose, CA, United States). FlowJo software (Tree Star, Inc., Ashland, OR, United States) was used to analyze and display the data.

\section{Competitive repopulation}

BM cells from WT, $5 \mathrm{~A} 3^{+/ d e l}$, Gata2 ${ }^{+/-}$, Gata2 ${ }^{+/-} 5 \mathrm{~A} 3^{+/ d e l}$ mice on a C57BL/6J background (CD45.2) were used as donor cells. Competitor cells were isolated from 8- to 12-week-old BoyJ mice (CD45.1). Recipient F1 hybrid mice from a cross between C57BL/6J and BoyJ mice (CD45.1 + CD45.2) were at least 8 weeks old at the time of lethal irradiation $(9.5 \mathrm{~Gy}$ from a cesium source delivered in split dose $3 \mathrm{hr}$ apart). After irradiation, the cells were injected via the tail vein of recipient mice. For evaluation of the competitiveness of whole BM, we injected $10^{6}$ whole BM cells at a 1:1 or 1:2 donor to competitor ratio. To evaluate the repopulating potential of purified CD150 hi-HSC, we injected 15 CD150 hi $-H S C$ sorted from 8- to 12 -week-old WT and $5 \mathrm{~A}^{+/ \text {del }}$ mice together with $2.5 \times 10^{5} \mathrm{BM}$ competitor cells into lethally irradiated recipients.

Blood was obtained from recipient mice every 30 days beginning 1 month after transplant, and cells were stained with Alexa Fluor 700 CD45.2 (104), PE-Cy7 CD45.1 (A20), PacBlue B220 (RA3-6B2), 
FITC CD4 (GK1.5), FITC CD8 (53-6.7), PE Mac-1 (M1/70), and PE Gr-1 (RB6-8C5) to determine the percent donor cell contribution to myeloid and $B$ and $T$ lymphoid lineages. Primary recipient mice were euthanized 6 months after transplantation, BM were isolated from the tibiae and femur, and $2 \times 10^{6} \mathrm{BM}$ cells were injected into secondary recipients to test serial repopulation potential. To determine the contribution of donor-derived cells in the $\mathrm{K}^{+} \mathrm{L}^{-} \mathrm{S}^{+}$compartment, $\mathrm{BM}$ cells were stained with V450 CD45.2 (104), APC-780 CD45.1 (A20), PE B220 (RA3-6B2), PE CD8 (53-6.7), PE Gr-1 (RB6-8C5), PE CD3 (17A2), PE Ter119 (TER-119), PE-Cy7 c-kit (2B8), and APC Sca-1 (E13161.7). Secondary recipients were analyzed as in the primary recipients.

\section{Methylcellulose colony assays}

CD150 hi $-H S C, C D 150^{10}-H S C$, and CD150 ${ }^{\text {neg }}-M P P$ were isolated as described above, and 100 cells were seeded into methylcellulose medium as described (Mohrin et al., 2010). Colonies were counted on day 7 , and the entire contents of a methylcellulose culture from an individual plate were then flushed out using phosphate-buffered saline and counted in a hemocytometer. Cells were also spun in a Cytospin 3 Cytocentrifuge (Shandon/Thermo Fisher Scientific, Waltham, MA, United States) at 400 rpm for $8 \mathrm{~min}$, and differential cell counting and morphological analysis performed after WrightGiemsa staining.

\section{RNA isolation and expression}

CD150 hi $-H S C, C D 150^{10}-H S C$, and CD150 neg-MPP were sorted as above into $500 \mu \mathrm{l}$ of TRlzol reagent (Life Technologies, Grand Island, NY, United States). RNA was isolated according to manufacturer's instructions and precipitated with the addition of glycogen (New England BioLabs, Ipswich, MA, United States). The RNA was then treated with DNAse 1 (Ambion, Austin, TX, United States) and purified with the RNeasy MinElute Cleanup Kit (Qiagen, Valencia, CA, United States).

For TaqMan analysis, reverse transcription was carried out using the High Capacity RNA-to-cDNA Master Mix (Life Technologies). Relative quantification of gene expression was determined by performing quantitative real-time PCR using the following TaqMan Gene Expression Assays (Applied Biosystems): Armc10 (Mm03011576_g1), Mll5 (Mm01129502_g1), Napepld (Mm00724596_m1), Orc5 (Mm00457242_m1), Psmc2 (Mm00803207_m1), Dnajc2 (Mm00494389_m1), Pmpcb (Mm01138654_m1), Srpk2 (Mm00486413_m1), Fbxl13 (Mm00622025_m1), Lrrc17 (Mm01167263_m1), Slc26a5 (Mm00446145_m1), Reln (Mm00465200_m1), Lhfpl3 (Mm03038441_m1), and Gapdh (Mm99999915_g1) with the TaqMan Gene Expression Master Mix (ABI). PCR reactions were performed on an ABI 7900HT Real-Time PCR System (Applied Biosystems, Foster City, CA, United States) with the Taqman Gene Expression Master Mix (Applied Biosystems) according to manufacturer's instructions. PCR cycling conditions were $2 \mathrm{~min}$ at $50^{\circ} \mathrm{C}$ and $10 \mathrm{~min}$ at $95^{\circ} \mathrm{C}$, followed by 40 cycles of $15 \mathrm{~s}$ at $95^{\circ} \mathrm{C}$ and $1 \mathrm{~min}$ at $60^{\circ} \mathrm{C}$. All reactions were carried out in triplicate, and target quantities were determined using a relative standard curve. The amounts of target were normalized to the endogenous control gene Gapdh and compared with the corresponding WT BM (calibrator sample) to determine relative fold differences.

For RNA-Seq analysis, total RNA (10 ng) was converted into double-stranded cDNA using the Ovation RNA Amplification System V2 (NuGen, San Carlo, CA, United States) per manufacturer's recommendations. The amplified cDNA products were then used to generate RNA-seq libraries using the TruSeq RNA Sample Preparation Kit v2 reagents (Illumina, San Diego, CA, United States) per manufacturer's instructions, with 10 PCR amplification cycles. Library quality and quantity were assessed by the Agilent DNA1000 Chip (Agilent, Santa Clara, CA, United States) and qPCR (Kappa Biosystems Inc, Woburn, MA, United States). 10 pM of each library was sequenced using Illumina SBS chemistry at $2 \times 100$ bp reads on the HiSeq2000 (Illumina, San Diego, CA, United States).

The RNA-Seq paired-end reads were mapped to the mouse $\mathrm{mm} 9$ genome using an in-house mapping and quality assessment pipeline (Zhang et al., 2012). The expression of each gene was estimated by the mean coverage of the highest covered coding exon. Genes with low-expression level $(<10)$ across all samples were filtered out, followed by quantile normalization. Differential expression analysis was performed using limma (Smyth, 2004) with estimation of false discovery rate (Benjamini and Hochberg, 1995). GSEA (Subramanian et al., 2005, 2007) was used to assess pathway enrichment. 


\section{ATP quantification}

HSC and MPP were sorted into phosphate buffered saline (PBS), and 600 CD150 hi $-H_{S C}, 1000$ CD150 ${ }^{\text {o }}$ HSC, and 1000 CD150 ${ }^{\text {neg-MPP }}$ were aliquoted into a well of a 96-well plate in triplicate. ATP was quantified using the CellTiter-Glo Luminescent Cell Viability Assay (Promega, Madison, WI, United States) following manufacturer's recommendations. Illumination was quantified with a Synergy 2 (Biotek, Winooski, VT, United States).

\section{Metabolic studies}

For flow cytometric analysis of ROS levels and membrane potential in CD150 hi -HSC, CD150 lo-HSC, and CD150 neg-MPP, BM cells were isolated and enriched for c-kit positive cells as described. c-kit positive cells were stained with an unconjugated cocktail of purified antibodies including B220 (RA3-6B2), CD8 (53-6.7), Gr-1 (RB6-8C5), CD3 (17A2), Ter119 (TER-119), and CD41 (MWReg30) from BioLegend, followed by PECy-5 IgG GOAT anti-RAT pAb (HI47) antibody from Molecular Probes and IgG from rat serum (14131 Sigma). After incubation with $50 \mathrm{nM}$ CellROX Orange Reagent (Molecular Probes) or 20 nM MitoTracker Orange CMTMRos (Molecular Probes, Eugene, OR, United States) for $30 \mathrm{~min}$ at $37^{\circ} \mathrm{C}$ in IMDM, cells were washed and stained with 7-amino-actinomycin D, PE-Cy7 c-kit (2B8), PacBlue Sca-1 (E13-161.7), PE-Cy5 CD48 (HM48-1), and APC CD150 (TC15-12F12.2) from BioLegend.

The OCR was analyzed in an XF96 extracellular flux analyzer following manufacturer's protocol (Seahorse Biosciences, Billerica, MA, United States). Freshly isolated $\mathrm{K}^{+} \mathrm{L}^{-} \mathrm{S}^{+}$cells and $\mathrm{K}^{+} \mathrm{L}^{-} \mathrm{S}^{-}$cells were cultured in StemSpan serum-free medium (STEMCELL Technologies, Vancouver, Canada) supplemented with SCF $(100 \mathrm{ng} / \mathrm{ml})$ and Tpo $(100 \mathrm{ng} / \mathrm{ml})$, while freshly isolated thymic cells and B-220 ${ }^{+}$splenic cells were cultured in RPMI medium 1640 supplemented with $10 \%$ fetal calf serum and incubated at $37^{\circ}$ in a humidified atmosphere containing $8 \% \mathrm{CO}_{2}$ for $12-15 \mathrm{hr}$. Cells were then washed three times with Mito Stress Media (XF base media supplemented with glucose [3 $\mathrm{mg} / \mathrm{ml}$, sodium pyruvate [1 $\mathrm{mM}$, and Glutamax [2 mM] adjusted to a $\mathrm{pH}=7.4$ ) and seeded in XF96 microplates coated with poly-L-lysine (Sigma). $60000 \mathrm{~K}^{+} \mathrm{L}^{-} \mathrm{S}^{+}$cells, $100000 \mathrm{~K}^{+} \mathrm{L}^{-} \mathrm{S}^{-}$cells, 200000 thymic cells, and $200000 \mathrm{~B} 220^{+}$splenic cells were plated per well, respectively. $\mathrm{K}^{+} \mathrm{L}^{-} \mathrm{S}^{+}$and $\mathrm{K}^{+} \mathrm{L}^{-} \mathrm{S}^{-}$cells were stimulated with SCF $(100 \mathrm{ng} / \mathrm{ml})$ and Tpo $(100$ $\mathrm{ng} / \mathrm{ml})$, while thymic cells were stimulated with interleukin (IL)-2 (20 ng/ml) and IL-7 (10 ng/ml) and $\mathrm{B}-220^{+}$splenic cells were stimulated with $\mathrm{IL}-7(10 \mathrm{ng} / \mathrm{ml})$ and maintained in a non $-\mathrm{CO}_{2}$ incubator for $1 \mathrm{hr}$ before the assay. Five baseline recordings were made, followed by sequential injection of Oligomycin (Sigma), Carbonyl Cyanide 4-(trifluoromethoxy)phenylhydrazone (Sigma), and a combination of Antimycin A (Sigma) and Rotenone (Sigma) to determine the mitochondrial respiration rate under various conditions.

\section{Statistical analysis}

Data are presented as mean values \pm SEM unless stated otherwise. Statistical significance was determined by performing two-tailed Student's t-tests.

\section{Antibodies for flow cytometry of CLP cells}

CLP were identified and evaluated by flow cytometry by staining with a lineage cocktail of PE-conjugated antibodies including B220 (RA3-6B2), CD8 (53-6.7), Gr-1 (RB6-8C5), CD3 (17A2), and Ter119 (TER-119), as well as APC-750 c-kit (2B8), PacBlue Sca-1 (E13-161.7), APC IL-7R $\alpha$ (A7R34) and biotin Flk2 (A2F10), and a streptavidin PE-Cy7 conjugate (BioLegend).

\section{BrdU staining}

Mice received an initial intraperitoneal injection of BrdU (Sigma-Aldrich, $1 \mathrm{mg} / 6 \mathrm{~g}$ mouse weight) and were then maintained on $1.0 \mathrm{mg} / \mathrm{ml} \mathrm{BrdU}$ in the drinking water $24 \mathrm{hr}$ prior to sacrifice. To measure BrdU incorporation, BM cells were enriched for c-kit positive cells using c-kit antibody-conjugated microbeads (Miltenyi). Enriched BM cells were pre-incubated with purified CD16/32 (2.4G2), followed by staining with a lineage cocktail of PE-conjugated antibodies including B220 (RA3-6B2), CD8 (53-6.7), Gr-1 (RB6-8C5), CD3 (17A2), Ter119 (TER-119), as well as PECy7 c-kit (2B8) and PacBlue Sca-1 (E13-161.7) (BioLegend). BrdU incorporation was then assayed according to manufacturer's instructions of the APC BrdU Flow Kit (BD Pharmingen, San Jose, CA, United States). 


\section{NHS-biotin staining}

NHS-biotin (EZ-Link Sulfo-NHS-LC-LC-biotin; Life Technologies) was dissolved at $10 \mathrm{mg} / \mathrm{ml}$ in normal saline and injected into mice intravenously via the tail vein at $1 \mathrm{mg} / 6 \mathrm{~g}$ mouse weight. To assess biotin dilution in the HSC subpopulations, BM cells were enriched for c-kit positive cells using c-kit antibodyconjugated microbeads (Miltenyi). Enriched cells were pre-incubated with purified CD16/32 (2.4G2), followed by staining with a lineage cocktail of PE-conjugated antibodies including B220 (RA3-6B2), CD8 (53-6.7), Gr-1 (RB6-8C5), CD3 (17A2), Ter119 (TER-119), CD41 (MWReg30), and CD48 (HM48-1), as well as PerCP/Cy5.5 c-kit (2B8), PacBlue Sca-1 (E13-161.7), APC CD150 (TC15-12F12.2), and PECy-7-conjugated Streptavidin (BioLegend).

\section{Acknowledgements}

We are grateful to Michelle Le Beau, Qing Li, Scott Lowe, and Megan McNerney for insightful suggestions and to Stuart Orkin for providing the Gata2 ${ }^{+-}$mutant mice. This work was supported by NIH grants P01 CA40046, R37 CA72614, T32 CA108462, and R01 HL092471, by the Kenneth and Mary Ellen Wilson St. Baldrick's Research Grant, by a Specialized Center of Research award from the Leukemia and Lymphoma Society (LLS 7019-04), and by the ALSAC of St. Jude Children's Research Hospital. KS is an American Cancer Society Research Professor, MRB is supported by the American Cancer Society Hillcrest Fellowship, and EP is a Leukemia and Lymphoma Society Scholar.

\section{Additional information}

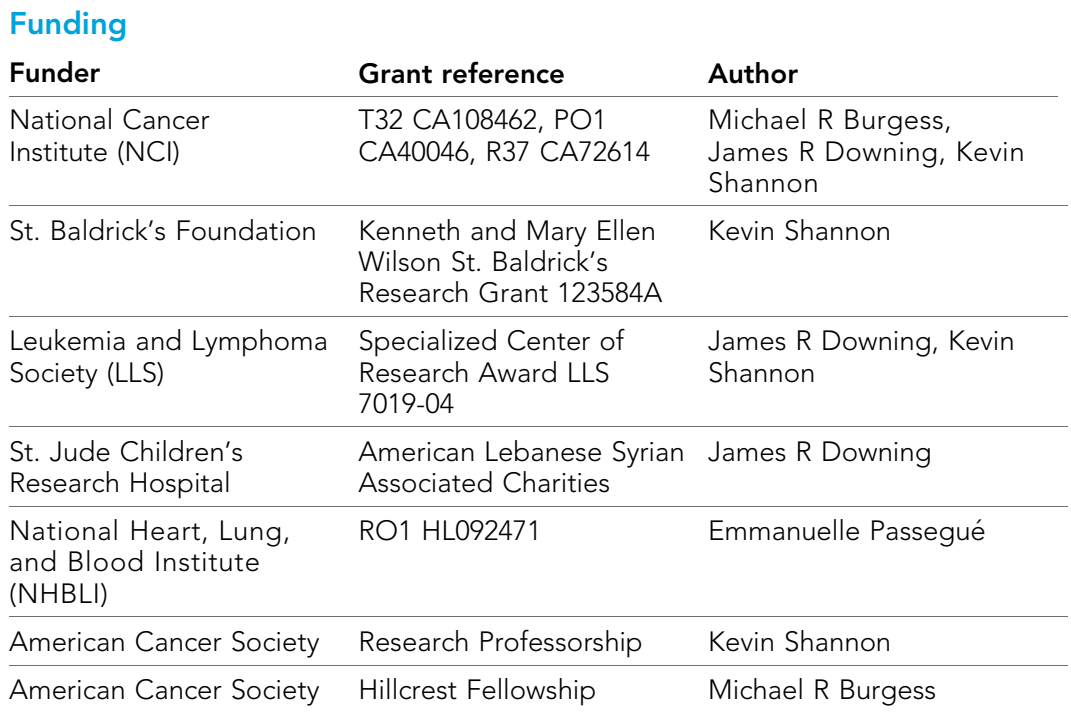

The funders had no role in study design, data collection and interpretation, or the decision to submit the work for publication.

Author contributions

JCW, KMW, Conception and design, Acquisition of data, Analysis and interpretation of data, Drafting or revising the article; MA, JN, JC, JF, DR, Acquisition of data, Analysis and interpretation of data, Drafting or revising the article; SCK, JM, S-CC, Analysis and interpretation of data, Drafting or revising the article; MRB, Acquisition of data, Drafting or revising the article, Contributed unpublished essential data or reagents; $Y Z$, Drafting or revising the article, Contributed unpublished essential data or reagents; TTH, Acquisition of data, Drafting or revising the article; EP, JRD, KS, Conception and design, Analysis and interpretation of data, Drafting or revising the article

Ethics

Animal experimentation: Study mice were housed in a specific pathogen-free facility at the University of California San Francisco, and all animal experiments were conducted in strict accordance with the protocols approved by the Institutional Animal Care and Use Committee (IACUC) of the University of California, San Francisco (Approval number: AN091877-03). 


\section{Additional files}

Major dataset

The following dataset was generated:

\begin{tabular}{|c|c|c|c|c|}
\hline Author(s) & Year & Dataset title & $\begin{array}{l}\text { Dataset ID } \\
\text { and/or URL }\end{array}$ & $\begin{array}{l}\text { Database, license, and } \\
\text { accessibility information }\end{array}$ \\
\hline $\begin{array}{l}\text { Wong JC, Weinfurtner } \\
\text { KM, Alzamora M, } \\
\text { Kogan SC, Burgess MR, } \\
\text { Zhang Y, Nakitandwe J, } \\
\text { Ma J, Cheng J, Chen S, }\end{array}$ & 2015 & $\begin{array}{l}\text { Data from: Functional } \\
\text { evidence implicating } \\
\text { chromosome } 7 q 22 \\
\text { haploinsufficiency in } \\
\text { myelodysplastic }\end{array}$ & $\begin{array}{l}\text { http://www.ncbi.nlm.nih. } \\
\text { gov/geo/query/acc.cgi? } \\
\text { acc=GSE72811 }\end{array}$ & $\begin{array}{l}\text { Available at Gene } \\
\text { Expression Omnibus } \\
\text { (GEO) with the accession } \\
\text { number GSE72811. }\end{array}$ \\
\hline
\end{tabular}

Ma J, Cheng J, Chen S,

myelodysplastic

Ho TT, Flach J,
Reynaud D, Passegue E,

Downing JR, Shannon K

\section{References}

Abrahamson G, Boultwood J, Madden J, Kelly S, Oscier DG, Rack K, Buckle VJ, Wainscoat JS. 1991. Clonality of cell populations in refractory anaemia using combined approach of gene loss and X-linked restriction fragment length polymorphism-methylation analyses. British Journal of Haematology 79:550-555. doi: 10.1111/j.13652141.1991.tb08080.x.

Asou H, Matsui H, Ozaki Y, Nagamachi A, Nakamura M, Aki D, Inaba T. 2009. Identification of a common microdeletion cluster in 7q21.3 subband among patients with myeloid leukemia and myelodysplastic syndrome. Biochemical and Biophysical Research Communications 383:245-251. doi: 10.1016/j.bbrc.2009.04.004.

Beerman I, Bhattacharya D, Zandi S, Sigvardsson M, Weissman IL, Bryder D, Rossi DJ. 2010a. Functionally distinct hematopoietic stem cells modulate hematopoietic lineage potential during aging by a mechanism of clonal expansion. Proceedings of the National Academy of Sciences of USA 107:5465-5470. doi: 10.1073/pnas. 1000834107.

Beerman I, Maloney WJ, Weissmann IL, Rossi DJ. 2010b. Stem cells and the aging hematopoietic system. Current Opinion in Immunology 22:500-506. doi: 10.1016/j.coi.2010.06.007.

Benjamini Y, Hochberg Y. 1995. Controlling the false discovery rate: a practical andpowerful approach to multiplet testing. Journal of the Royal Statistical Society Series B (Methodological) 57:289-300.

Bernell P, Jacobsson B, Nordgren A, Hast R. 1996. Clonal cell lineage involvement in myelodysplastic syndromes studied by fluorescence in situ hybridization and morphology. Leukemia 10:662-668.

Beurlet S, Chomienne C, Padua RA. 2013. Engineering mouse models with myelodysplastic syndrome human candidate genes; how relevant are they? Haematologica 98:10-22. doi: 10.3324/haematol.2012.069385.

Bodor C, Renneville A, Smith M, Charazac A, lqbal S, Etancelin P, Cavenagh J, Barnett MJ, Kramarzová K, Krishnan B, Matolcsy A, Preudhomme C, Fitzgibbon J, Owen C. 2012. Germ-line GATA2 p.THR354MET mutation in familial myelodysplastic syndrome with acquired monosomy 7 and ASXL1 mutation demonstrating rapid onset and poor survival. Haematologica 97:890-894. doi: 10.3324/haematol.2011.054361.

Chen C, Liu Y, Rappaport AR, Kitzing T, Schultz N, Zhao Z, Zhao Z, Shroff AS, Dickins RA, Vakoc CR, Bradner JE, Stock W, LeBeau MM, Shannon KM, Kogan S, Zuber J, Lowe SW. 2014. MLL3 is a haploinsufficient 7q tumor suppressor in acute myeloid leukemia. Cancer Cell 25:652-665. doi: 10.1016/j.ccr.2014.03.016.

Ebert BL. 2011. Molecular dissection of the $5 q$ deletion in myelodysplastic syndrome. Seminars in Oncology 38 : 621-626. doi: 10.1053/j.seminoncol.2011.04.010.

Elias HK, Schinke C, Bhattacharyya S, Will B, Verma A, Steidl U. 2014. Stem cell origin of myelodysplastic syndromes. Oncogene 33:5139-5150. doi: 10.1038/onc.2013.520.

Ernst T, Chase AJ, Score J, Hidalgo-Curtis CE, Bryant C, Jones AV, Waghorn K, Zoi K, Ross FM, Reiter A, Hochhaus A, Drexler HG, Duncombe A, Cervantes F, Oscier D, Boultwood J, Grand FH, Cross NC. 2010. Inactivating mutations of the histone methyltransferase gene EZH2 in myeloid disorders. Nature Genetics 42:722-726. doi: 10.1038/ng.621.

Fischer K, Frohling S, Scherer SW, McAllister Brown J, Scholl C, Stilgenbauer S, Tsui LC, Lichter P, Döhner H. 1997. Molecular cytogenetic delineation of deletions and translocations involving chromosome band 7q22 in myeloid leukemias. Blood 89:2036-2041.

Fujiki R, Chikanishi T, Hashiba W, Ito H, Takada I, Roeder RG, Kitagawa H, Kato S. 2009. GlcNAcylation of a histone methyltransferase in retinoic-acid-induced granulopoiesis. Nature 459:455-459. doi: 10.1038/nature07954.

Hahn CN, Chong CE, Carmichael CL, Wilkins EJ, Brautigan PJ, Li XC, Li XC, Babic M, Lin M, Carmagnac A, Lee YK, Kok CH, Gagliardi L, Friend KL, Ekert PG, Butcher CM, Brown AL, Lewis ID, To LB, Timms AE, Storek J, Moore S, Altree M, Escher R, Bardy PG, Suthers GK, D’Andrea RJ, Horwitz MS, Scott HS. 2011. Heritable GATA2 mutations associated with familial myelodysplastic syndrome and acute myeloid leukemia. Nature Genetics 43:1012-1017. doi: 10.1038/ng.913.

Hock H. 2010. Some hematopoietic stem cells are more equal than others. The Journal of Experimental Medicine 207:1127-1130. doi: 10.1084/jem.20100950.

Hosono N, Makishima H, Jerez A, Yoshida K, Przychodzen B, McMahon S, Shiraishi Y, Chiba K, Tanaka H, Miyano S, Sanada M, Gómez-Seguí I, Verma AK, McDevitt MA, Sekeres MA, Ogawa S, Maciejewski JP. 2014. Recurrent genetic defects on chromosome 7q in myeloid neoplasms. Leukemia 28:1348-1351. doi: 10.1038/leu.2014.25. 
Jang YY, Sharkis SJ. 2007. A low level of reactive oxygen species selects for primitive hematopoietic stem cells that may reside in the low-oxygenic niche. Blood 110:3056-3063. doi: 10.1182/blood-2007-05-087759.

Jerez A, Sugimoto Y, Makishima H, Verma A, Jankowska AM, Przychodzen B, Visconte V, Tiu RV, O'Keefe CL, Mohamedali AM, Kulasekararaj AG, Pellagatti A, McGraw K, Muramatsu H, Moliterno AR, Sekeres MA, McDevitt MA, Kojima S, List A, Boultwood J, Mufti GJ, Maciejewski JP. 2012. Loss of heterozygosity in 7q myeloid disorders: clinical associations and genomic pathogenesis. Blood 119:6109-6117. doi: 10.1182/ blood-2011-12-397620.

Kere J, Ruutu T, Davies KA, Roninson IB, Watkins PC, Winqvist R, de la Chapelle A. 1989. Chromosome 7 long arm deletion in myeloid disorders: a narrow breakpoint region in 7q22 defined by molecular mapping. Blood 73: 230-234.

Kere J, Ruutu T, Lahtinen R, de la Chapelle A. 1987a. Molecular characterization of chromosome 7 long arm deletions in myeloid disorders. Blood 70:1349-1353.

Kere J, Ruutu U, Lahtinen R, de la Chapelle A. 1987b. Monosomy 7 in granulocytes and monocytes in myelodysplastic syndrome. The New England Journal of Medicine 316:499-504. doi: 10.1056/ NEJM198702263160902.

Kiel MJ, Yilmaz OH, Iwashita T, Yilmaz OH, Terhorst C, Morrison SJ. 2005. SLAM family receptors distinguish hematopoietic stem and progenitor cells and reveal endothelial niches for stem cells. Cell 121:1109-1121. doi: 10.1016/j.cell.2005.05.026.

Le Beau MM, Espinosa R III, Davis EM, Eisenbart JD, Larson RA, Green ED. 1996. Cytogenetic and molecular delineation of a region of chromosome 7 commonly deleted in malignant myeloid diseases. Blood 88:1930-1935.

Li L, Li M, Sun C, Francisco L, Chakraborty S, Sabado M, McDonald T, Gyorffy J, Chang K, Wang S, Fan W, Li J, Zhao LP, Radich J, Forman S, Bhatia S, Bhatia R. 2011. Altered hematopoietic cell gene expression precedes development of therapy-related myelodysplasia/acute myeloid leukemia and identifies patients at risk. Cancer Cell 20:591-605. doi: 10.1016/j.ccr.2011.09.011.

Liang H, Fairman J, Claxton DF, Nowell PC, Green ED, Nagarajan L. 1998. Molecular anatomy of chromosome 7q deletions in myeloid neoplasms: evidence for multiple critical loci. Proceedings of the National Academy of Sciences of USA 95:3781-3785. doi: 10.1073/pnas.95.7.3781.

Luciano P, Geoffroy S, Brandt A, Hernandez JF, Geli V. 1997. Functional cooperation of the mitochondrial processing peptidase subunits. Journal of Molecular Biology 272:213-225. doi: 10.1006/jmbi.1997.1231.

McNerney ME, Brown CD, Wang X, Bartom ET, Karmakar S, Bandlamudi C, Yu S, Ko J, Sandall BP, Stricker T, Anastasi J, Grossman RL, Cunningham JM, Le Beau MM, White KP. 2013. CUX1 is a haploinsufficient tumor suppressor gene on chromosome 7 frequently inactivated in acute myeloid leukemia. Blood 121:975-983. doi: 10.1182/blood-2012-04-426965.

Mohrin M, Bourke E, Alexander D, Warr MR, Barry-Holson K, Le Beau MM, Morrison CG, Passegué E. 2010. Hematopoietic stem cell quiescence promotes error-prone DNA repair and mutagenesis. Cell Stem Cell 7: 174-185. doi: 10.1016/j.stem.2010.06.014.

Mootha VK, Lindgren CM, Eriksson KF, Subramanian A, Sihag S, Lehar J, Puigserver $P$, Carlsson E, Ridderstråle M, Laurila E, Houstis N, Daly MJ, Patterson N, Mesirov JP, Golub TR, Tamayo P, Spiegelman B, Lander ES, Hirschhorn JN, Altshuler D, Groop LC. 2003. PGC-1alpha-responsive genes involved in oxidative phosphorylation are coordinately downregulated in human diabetes. Nature Genetics 34:267-273. doi: 10.1038/ng1180.

Nagamachi A, Matsui H, Asou H, Ozaki Y, Aki D, Kanai A, Takubo K, Suda T, Nakamura T, Wolff L, Honda H, Inaba T. 2013. Haploinsufficiency of SAMD9L, an endosome fusion facilitator, causes myeloid malignancies in mice mimicking human diseases with monosomy 7. Cancer Cell 24:305-317. doi: 10.1016/j.ccr.2013.08.011.

Nijhawan D, Zack TI, Ren Y, Strickland MR, Lamothe R, Schumacher SE, Tsherniak A, Besche HC, Rosenbluh J, Shehata S, Cowley GS, Weir BA, Goldberg AL, Mesirov JP, Root DE, Bhatia SN, Beroukhim R, Hahn WC. 2012. Cancer vulnerabilities unveiled by genomic loss. Cell 150:842-854. doi: 10.1016/j.cell.2012.07.023.

Nikoloski G, Langemeijer SM, Kuiper RP, Knops R, Massop M, Tonnissen ER, van der Heijden A, Scheele TN, Vandenberghe $P$, de Witte T, van der Reijden BA, Jansen JH. 2010. Somatic mutations of the histone methyltransferase gene EZH2 in myelodysplastic syndromes. Nature Genetics 42:665-667. doi: 10.1038/ng.620.

Nygren JM, Bryder D. 2008. A novel assay to trace proliferation history in vivo reveals that enhanced divisional kinetics accompany loss of hematopoietic stem cell self-renewal. PLOS ONE 3:e3710. doi: 10.1371/journal.pone. 0003710.

Pang WW, Pluvinage JV, Price EA, Sridhar K, Arber DA, Greenberg PL, Schrier SL, Park CY, Weissman IL. 2013. Hematopoietic stem cell and progenitor cell mechanisms in myelodysplastic syndromes. Proceedings of the National Academy of Sciences of USA 110:3011-3016. doi: 10.1073/pnas.1222861110.

Pasquet M, Bellanne-Chantelot C, Tavitian S, Prade N, Beaupain B, Larochelle O, Petit A, Rohrlich P, Ferrand C, Van Den Neste E, Poirel HA, Lamy T, Ouachée-Chardin M, Mansat-De Mas V, Corre J, Récher C, Plat G, Bachelerie F, Donadieu J, Delabesse E. 2013. High frequency of GATA2 mutations in patients with mild chronic neutropenia evolving to MonoMac syndrome, myelodysplasia, and acute myeloid leukemia. Blood 121:822-829. doi: 10.1182/blood-2012-08-447367.

Poetsch AR, Lipka DB, Witte T, Claus R, Nollke P, Zucknick M, Olk-Batz C, Fluhr S, Dworzak M, De Moerloose B, Starý J, Zecca M, Hasle H, Schmugge M, van den Heuvel-Eibrink MM, Locatelli F, Niemeyer CM, Flotho C, Plass C. 2014. RASA4 undergoes DNA hypermethylation in resistant juvenile myelomonocytic leukemia. Epigenetics 9 : 1252-1260. doi: 10.4161/epi.29941.

Quintana DG, Thome KC, Hou ZH, Ligon AH, Morton CC, Dutta A. 1998. ORC5L, a new member of the human origin recognition complex, is deleted in uterine leiomyomas and malignant myeloid diseases. The Journal of Biological Chemistry 273:27137-27145. doi: 10.1074/jbc.273.42.27137. 
Reinecke F, Smeitink JA, van der Westhuizen FH. 2009. OXPHOS gene expression and control in mitochondrial disorders. Biochimica et Biophysica Acta 1792:1113-1121. doi: 10.1016/j.bbadis.2009.04.003.

Richly H, Rocha-Viegas L, Ribeiro JD, Demajo S, Gundem G, Lopez-Bigas N, Nakagawa T, Rospert S, Ito T, Di Croce L. 2010. Transcriptional activation of polycomb-repressed genes by ZRF1. Nature 468:1124-1128. doi: 10. 1038/nature09574.

Rodrigues NP, Janzen V, Forkert R, Dombkowski DM, Boyd AS, Orkin SH, Enver T, Vyas P, Scadden DT. 2005. Haploinsufficiency of GATA-2 perturbs adult hematopoietic stem-cell homeostasis. Blood 106:477-484. doi: 10. 1182/blood-2004-08-2989.

Sebastian S, Sreenivas P, Sambasivan R, Cheedipudi S, Kandalla P, Pavlath GK, Dhawan J. 2009. MLL5, a trithorax homolog, indirectly regulates $\mathrm{H} 3 \mathrm{~K} 4$ methylation, represses cyclin $\mathrm{A} 2$ expression, and promotes myogenic differentiation. Proceedings of the National Academy of Sciences of USA 106:4719-4724. doi: 10.1073/pnas. 0807136106.

Serrat R, Mirra S, Figueiro-Silva J, Navas-Perez E, Quevedo M, Lopez-Domenech G, Podlesniy P, Ulloa F, GarciaFernàndez J, Trullas R, Soriano E. 2014. The Armc10/SVH gene: genome context, regulation of mitochondrial dynamics and protection against Abeta-induced mitochondrial fragmentation. Cell Death \& Disease 5:e1163. doi: 10.1038/cddis.2014.121.

Smith SM, Le Beau MM, Huo D, Karrison T, Sobecks RM, Anastasi J, Vardiman JW, Rowley JD, Larson RA. 2003. Clinical-cytogenetic associations in 306 patients with therapy-related myelodysplasia and myeloid leukemia: the University of Chicago series. Blood 102:43-52.

Smyth GK. 2004. Linear models and empirical bayes methods for assessing differential expression in microarray experiments. Statistical Applications in Genetics and Molecular Biology 3:Article3. doi: 10. 2202/1544-6115.1027.

Solimini NL, Xu Q, Mermel CH, Liang AC, Schlabach MR, Luo J, Burrows AE, Anselmo AN, Bredemeyer AL, Li MZ, Beroukhim R, Meyerson M, Elledge SJ. 2012. Recurrent hemizygous deletions in cancers may optimize proliferative potential. Science 337:104-109. doi: 10.1126/science.1219580.

Subramanian A, Kuehn H, Gould J, Tamayo P, Mesirov JP. 2007. GSEA-P: a desktop application for gene set enrichment analysis. Bioinformatics 23:3251-3253. doi: 10.1093/bioinformatics/btm369.

Subramanian A, Tamayo P, Mootha VK, Mukherjee S, Ebert BL, Gillette MA, Paulovich A, Pomeroy SL, Golub TR, Lander ES, Mesirov JP. 2005. Gene set enrichment analysis: a knowledge-based approach for interpreting genome-wide expression profiles. Proceedings of the National Academy of Sciences of USA 102:15545-15550. doi: 10.1073/pnas.0506580102.

Tosi S, Scherer SW, Giudici G, Czepulkowski B, Biondi A, Kearney L. 1999. Delineation of multiple deleted regions in 7q in myeloid disorders. Genes, Chromosomes \& Cancer 25:384-392. doi: 10.1002/(SICI)1098-2264(199908) 25:4<384::AID-GCC11>3.0.CO;2-D.

Tsai FY, Keller G, Kuo FC, Weiss M, Chen J, Rosenblatt M, Alt FW, Orkin SH. 1994. An early haematopoietic defect in mice lacking the transcription factor GATA-2. Nature 371:221-226. doi: 10.1038/371221a0.

Tsuboi K, Ikematsu N, Uyama T, Deutsch DG, Tokumura A, Ueda N. 2013. Biosynthetic pathways of bioactive Nacylethanolamines in brain. CNS \& Neurological Disorders Drug Targets 12:7-16. doi: 10.2174/ 1871527311312010005.

Warr MR, Passegue E. 2013. Metabolic makeover for HSCs. Cell Stem Cell 12:1-3. doi: 10.1016/j.stem.2012.12.005. Will B, Zhou L, Vogler TO, Ben-Neriah S, Schinke C, Tamari R, Yu Y, Bhagat TD, Bhattacharyya S, Barreyro L, Heuck C, Mo Y, Parekh S, McMahon C, Pellagatti A, Boultwood J, Montagna C, Silverman L, Maciejewski J, Greally JM, Ye BH, List AF, Steidl C, Steidl U, Verma A. 2012. Stem and progenitor cells in myelodysplastic syndromes show aberrant stage-specific expansion and harbor genetic and epigenetic alterations. Blood 120:2076-2086. doi: 10. 1182/blood-2011-12-399683.

Wong JC, Zhang Y, Lieuw KH, Tran MT, Forgo E, Weinfurtner K, Alzamora P, Kogan SC, Akagi K, Wolff L, Le Beau MM, Killeen N, Shannon K. 2010. Use of chromosome engineering to model a segmental deletion of chromosome band 7q22 found in myeloid malignancies. Blood 115:4524-4532. doi: 10.1182/blood-2009-07-232504.

Zhang J, Ding L, Holmfeldt L, Wu G, Heatley SL, Payne-Turner D, Easton J, Chen X, Wang J, Rusch M, Lu C, Chen SC, Wei L, Collins-Underwood JR, Ma J, Roberts KG, Pounds SB, Ulyanov A, Becksfort J, Gupta P, Huether R, Kriwacki RW, Parker M, McGoldrick DJ, Zhao D, Alford D, Espy S, Bobba KC, Song G, Pei D, Cheng C, Roberts S, Barbato MI, Campana D, Coustan-Smith E, Shurtleff SA, Raimondi SC, Kleppe M, Cools J, Shimano KA, Hermiston ML, Doulatov S, Eppert K, Laurenti E, Notta F, Dick JE, Basso G, Hunger SP, Loh ML, Devidas M, Wood B, Winter S, Dunsmore KP, Fulton RS, Fulton LL, Hong X, Harris CC, Dooling DJ, Ochoa K, Johnson KJ, Obenauer JC, Evans WE, Pui CH, Naeve CW, Ley TJ, Mardis ER, Wilson RK, Downing JR, Mullighan CG. 2012. The genetic basis of early T-cell precursor acute lymphoblastic leukaemia. Nature 481:157-163. doi: 10.1038/nature10725.

Zhou L, Opalinska J, Sohal D, Yu Y, Mo Y, Bhagat T, Abdel-Wahab O, Fazzari M, Figueroa M, Alencar C, Zhang J, Kambhampati S, Parmar S, Nischal S, Hueck C, Suzuki M, Freidman E, Pellagatti A, Boultwood J, Steidl U, Sauthararajah Y, Yajnik V, McMahon C, Gore SD, Platanias LC, Levine R, Melnick A, Wickrema A, Greally JM, Verma A. 2011. Aberrant epigenetic and genetic marks are seen in myelodysplastic leukocytes and reveal Dock4 as a candidate pathogenic gene on chromosome 7q. The Journal of Biological Chemistry 286:25211-25223. doi: 10.1074/jbc.M111.235028.

Zhou P, Wang Z, Yuan X, Zhou C, Liu L, Wan X, Zhang F, Ding X, Wang C, Xiong S, Wang Z, Yuan J, Li Q, Zhang Y. 2013. Mixed lineage leukemia 5 (MLL5) protein regulates cell cycle progression and E2F1-responsive gene expression via association with host cell factor-1 (HCF-1). The Journal of Biological Chemistry 288:17532-17543. doi: 10.1074/jbc.M112.439729. 